\title{
Functional morphology and food habits of deep-sea copepods of the genus Cephalophanes (Calanoida: Phaennidae): perception of bioluminescence as a strategy for food detection
}

\author{
Shuhei Nishida ${ }^{1, *}$, Susumu Ohtsuka ${ }^{2}$, Andrew R. Parker ${ }^{3}$ \\ ${ }^{1}$ Ocean Research Institute, University of Tokyo, 1-15-1 Minamidai, Nakano, Tokyo 164-8639, Japan \\ ${ }^{2}$ Fisheries Laboratory, Hiroshima University, 5-8-1 Minato-machi, Takehara, Hiroshima 725-0024, Japan \\ ${ }^{3}$ Department of Zoology, University of Oxford, South Parks Road, Oxford OX1 3PS, United Kingdom
}

\begin{abstract}
Deep-sea copepods of the genus Cephalophanes are characterised by their large eyes with semi-parabolic reflectors, but their ultrastructure and ecological significance have rarely been investigated. We examined the structure of the eyes, feeding appendages and digestive tract, and the gut contents of Cephalophanes spp., collected from deep-waters (500 to $1000 \mathrm{~m}$ ) of the subtropical western Pacific, through light and electron microscopic observations. The optic system of Cephalophanes spp. involves a pair of large, bilateral reflectors, each having anteriorly 2 dorso-ventrally arranged retinal cells and 1 more pair of retinal cells positioned posterior to each reflector. The reflector has a multilayer structure of thin (60 to $180 \mathrm{~nm}$ at the posterior end) plates decreasing in thickness from the inner to the outer sides of the reflector; the number of plates is ca. 10 to 20 near the anterior margin of the reflector, increasing posteriorly, and reaching ca. 80 near the apex of the reflector. The reflector provides a high ( 80 to $90 \%$ ) reflectance over a wide range of wavelengths (350 to $700 \mathrm{~nm}$ ) of incident light parallel to the reflector axis. The mandible gnathobase has thin blades arranged in parallel, and the setae on the gnathobase of the first maxilla and on the second maxilla and the maxilliped are slender with sparse setules, suggesting feeding on relatively large, inactive particles. In 27 out of the 101 specimens examined, a pear-shaped mass of unknown origin occupied the whole lumen of the well-defined anterior caecum of the midgut. In 25 of these 27 specimens, the lumen of the middle part of the midgut contained fragments of crustaceans, but essentially no other constituents of 'marine-snow' such as phytoplankton, protista, or other nanoplankton. Of the other 74 specimens examined, $97 \%$ had empty midguts. These observations suggest a specialization of the anterior midgut caecum for chitin digestion and a possible detection by Cephalophanes spp. of optical signals from crustacean carcasses, a nutritionally poor but ubiquitous food source in the deep sea.
\end{abstract}

KEY WORDS: Cephalophanes - Copepods - Optic system - Carcasses - Luminescence $\cdot$ Chitin digestion $\cdot$ Gut contents $\cdot$ Bacteria

\section{INTRODUCTION}

Recent investigations have revealed that many deep-sea copepods adopt specialized feeding modes that are uncommon in epipelagic habitats. In most of

*E-mail: nishida@ori.u-tokyo.ac.jp these copepods, their food habits revealed through gut-content analysis are consistent with their morphology, particularly in the structure of specialized sensory, feeding and/or digestive organs. These include different modes of detritivory that are assumed to be mediated by special chemosensory aesthetascs or elongated midguts in the species of 
Scolecitrichidae and related families (Nishida et al. 1991, Ohtsuka \& Kubo 1991, Steinberg et al. 1994, Nishida \& Ohtsuka 1997), different modes of carnivory by the possible use of mucus jets in the genus Euchirella (Cahoon 1982), injection of venom/anesthetics through hypodermic-needle-like teeth in Heterorhabdus spp. (Nishida \& Ohtsuka 1996, Ohtsuka et al. 1997), and capture of prey with specialized button setae in species of Augaptilidae (Krishnaswamy et al. 1967, Boxshall 1985, Matsuura \& Nishida 2000).

Deep-sea copepods of the genus Cephalophanes have a well-developed eye consisting of a pair of large, bilateral reflectors, each having anteriorly 2 dorsoventrally arranged retinal cells (Steuer 1928, see also review by Boxshall 1992). Steuer (1928) considered that the reflectors are modified lateral cups of a median eye, whose ventral cup has become totally reduced, and that the eyes are optimized for detection of the direction of incident light and have a structure comparable to those in the deep-sea planktonic ostracods Gigantocypris spp. (see also Land 1984, Herring 1994). Steuer (1928) also found a gut of Cephalophanes sp. filled with chitinous fragments of crustaceans, and suggested that the 'rain of carcasses (Leichenregen)' should be taken into account as a primary food source. These observations suggest the possible use of optical information by these deep-sea crustaceans, presumably related to their food habits. However, information on the structure of relevant organs and feeding ecology is still limited.

This study examines the fine structures of the optic, feeding, and digestive organs and gut contents of certain species of Cephalophanes, and discusses the functions of these organs and the possible feeding strategy of the copepods themselves.

\section{MATERIALS AND METHODS}

Plankton samples were collected by oblique tows of an ORI net (mesh size: 0.33 or $0.69 \mathrm{~mm}$; Omori 1965) or an IsaacsKidd midwater trawl (mesh size: 0.5 or $1.0 \mathrm{~mm}$; Isaacs \& Kidd 1953) from mesopelagic depths $(<1000 \mathrm{~m})$ at a speed of ca. 2 knots in Sagami Bay, off the Nansei Islands, and in the tropical and subtropical western Pacific off the Philippines, Indonesia and Australia, during cruises of the TRV 'Toyoshio Maru' and the RVs 'Tansei Maru' and 'Hakuho Maru' in the years 1995 to 2000.

Immediately after capture, Cephalophanes spp. (C. refulgens, C. tectus or unidentified Copepodids IV to V) were sorted from the original samples and fixed in $2 \%$ glutaraldehyde and $2.5 \%$ paraformaldehyde at $4{ }^{\circ} \mathrm{C}$. After preservation for $1 \mathrm{wk}$ to $2 \mathrm{mo}$, some specimens were post-fixed for transmission (TEM) or for scanning (SEM) electron microscopy in $1 \% \mathrm{OsO}_{4}$ for $2 \mathrm{~h}$ at $4^{\circ} \mathrm{C}$, while the remaining specimens were subjected to light microscopy (LM) for gross morphology and gutcontent analysis. Both fixatives were in $0.1 \mathrm{M}$ Millonig's phosphate buffer ( $\mathrm{pH}$ 7.4). One specimen was frozen at $-80^{\circ} \mathrm{C}$ for later analysis of the 'anteriorcaecum body' (see below). The numbers and body lengths of specimens examined by the different microscopic methods are shown in Table 1.

The specimens for SEM, fixed as above, either intact or with the appendages or midguts removed from the body trunk, were dehydrated through a graded ethanol series to $100 \%$ ethanol, critical-point or freezedried, coated with gold and observed with a Jeol T-20 or an Akashi Alpha-25A SEM at an accelerating voltage of $15 \mathrm{kV}$. For gut-content analysis the midguts were dry-fractured (Toda et al. 1989) before coating with gold.

For TEM, the mouth appendages and swimming legs of the specimens were dissected off before fixation in $\mathrm{OsO}_{4}$ for better penetration of the fixative and resin. The post-fixed specimens were dehydrated as in the SEM preparation and embedded in Epon-812 resin. Ultra-thin (ca. $70 \mathrm{~nm}$ ) sections were stained with uranyl acetate and lead citrate, and examined with a Hitachi H-7100 TEM at an accelerating voltage of $100 \mathrm{kV}$. Semi-thin (ca. $1 \mu \mathrm{m}$ ) sections were stained with toluidine blue and examined under a light microscope (Nikon, Optiphot) for determination of gross morphology.

The optic performance of the reflector was examined visually. The cephalosome of a female Cephalophanes refulgens was removed from the rest of the body with
Table 1. Cephalophanes spp. Number of specimens examined by different microscopic methods and number with an 'anterior-caecum body' (ACB, percentage of total specimens in parentheses). Of the ACB-containing specimens, the number with crustacean fragments $(\mathrm{CF})$ in the lumen of the midzone of the midgut are also shown $(\mathrm{ACB}+\mathrm{CF})$. LM: light microscopy; TEM: transmission electron microscopy; SEM: scanning electron microscopy

\begin{tabular}{|c|c|c|c|c|c|c|c|}
\hline Species/stage & $\begin{array}{l}\text { Total length } \\
\quad(\mathrm{mm})\end{array}$ & LM & $\begin{array}{l}\text { Met } \\
\text { TEM }\end{array}$ & $\begin{array}{l}\text { hods } \\
\text { SEM }\end{array}$ & Total & $\begin{array}{l}\text { Specin } \\
\text { ACB }\end{array}$ & $\begin{array}{l}\text { nens with } \\
\mathrm{ACB}+\mathrm{CF}\end{array}$ \\
\hline $\begin{array}{l}\text { C. refulgens } \\
\text { adult female }\end{array}$ & $4.15-5.30$ & 39 & 13 & 1 & 53 & $13(25)$ & 12 \\
\hline $\begin{array}{l}\text { C. tectus } \\
\text { adult female }\end{array}$ & $3.15-4.50$ & 14 & 4 & 2 & 20 & $9(45)$ & 9 \\
\hline $\begin{array}{l}\text { Copepodid } \\
\text { IV and V }\end{array}$ & $2.75-4.15$ & 26 & 1 & 1 & 28 & $5(18)$ & 4 \\
\hline Total & & & & & 101 & $27(27)$ & 25 \\
\hline
\end{tabular}


a pair of ophthalmic scissors, put in a vial containing the preservative, and illuminated by white light either from underneath or from above, the latter by using a fiber optic light source (Nikon C-FID). The reflected and transmitted light from the reflector was then observed under a stereomicroscope (Nikon, SMZ-U).

The reflector was mathematically modeled to determine its optical properties and consequently the mechanism of reflectance. For this calculation, a program was used to calculate the reflectance and transmittance of a multilayer stack using the matrix method of Macleod (Macleod 1969, p. 35). The refractive indices of the cuticular layers were assumed to be 1.34 for the low index layer, which is probably essentially water, and 1.54 for the high index layer, assumed to be chitin (see Land 1972).

During a preliminary survey of the mid-gut structure, a pear-shaped mass hitherto not known from the midgut of Crustacea was found in the lumen of the anterior caecum of 27 out of the 101 copepods examined. This mass was tentatively termed the 'anteriorcaecum body' (ACB: see 'Results'), and was examined in some detail. Six specimens were fixed in glutaraldehyde-formaldehyde; their elemental composition and the effects of acid, base, and organic solvent on their physical macrostructure were examined. Two ACBs each were put in $10 \% \mathrm{HCl}$ or $10 \% \mathrm{KOH}$, heated at $80^{\circ} \mathrm{C}$ for $2 \mathrm{~h}$, and rinsed in distilled water. Another ACB was put in $100 \%$ acetone for $24 \mathrm{~h}$ and rinsed in distilled water. After these treatments, the texture and contents of the ACBs were examined under the stereomicroscope and the LM. One ACB was removed from a specimen, which had not been fixed in glutaraldehydeformaldehyde but preserved at $-80^{\circ} \mathrm{C}$ and then thawed at room temperature, and examined under the stereomicroscope and the LM. Two ACBs were rinsed in distilled water, air-dried, put on a double-sided carbon adhesive tape, and their surfaces were then examined for elemental composition in a Hitachi S-3000N TEM equipped with a Horiba EMAX 5770 energy-dispersive X-ray spectrometer (Si probe, EDX).

Gut contents were examined either by SEM, TEM, or LM (Table 1). For SEM, a freeze-dried midgut was put on double-sided adhesive tape attached to a stub. Another piece of tape was pressed down lightly on the specimen so that the midgut was fractured. The tape to which the fragments of midgut tissue adhered was remounted on the same or another stub. This procedure was repeated several times until the luminal surface with contents was exposed. The mounted specimens were gold-coated and the whole midgut area was examined in the SEM for presence, abundance, and types of gut-content material. For TEM, 1 to 3 cross-sections from the mid part of the midgut of each specimen were observed for the whole luminal area of each section. For LM, the whole midgut was removed from the prosome with dissecting needles and rinsed in a $10 \%$ glycerin/distilled-water solution to which had been added a small quantity of methyl blue, and its contents were developed on a slide in the same medium and observed under a light microscope.

\section{RESULTS}

The following descriptions are based on the specimens listed in Table 1 and the characteristics presented refer to those common to the adult females of both species unless specifically stated otherwise.

\section{Optic system}

The optic system consists primarily of a pair of large, bilateral reflectors which occupy a large area in the anterior region of the cephalosome and 4 pairs of dorso-ventrally arranged retinal cells. Of these retinal cells, 1 pair is located in the focal area of each reflector, and 1 pair is located posterior to the reflector, i.e. a total of 4 (Fig. 1A-C). Each reflector is parabolic in dorsal view but spherical in lateral view, with a concave margin dorsally and ventrally (Fig. 1A). A muscle band extends from the medial-dorsoanterior margin of each reflector, obliquely crossing the cephalon to the opposite dorsolateral cuticle; thus the pair of muscle bands cross each other medially (Fig. 1A).

The thickness of the reflector increases from the anterior margin to the posterior end (i.e. the apex of the parabola, which is $<10 \mu \mathrm{m}$ to ca. $20 \mu \mathrm{m}$ in Cephalophanes refulgens). The reflector contains a stack of thin plates, numbering 1 at the anterior end, increasing abruptly to ca. 10 to 20 near the medial-anterior margin (Fig. 1D), and reaching ca. 80 at the posterior end (Fig. 1E). The thickness of the thin plates decreases from the inside to the outside of the cup from ca. 250 to $100 \mathrm{~nm}$ at the medial-anterior end and from ca. 180 to $60 \mathrm{~nm}$ at the posterior end. The thin plates resemble the cuticle in density and texture and appear to be much softer than the guanine crystal of reflectors in many aquatic animals (Herring 1994), including the integumental reflector in copepods of the genera Sapphirina and Copilia (Chae \& Nishida 1994, Chae et al. 1996). The spaces between the plates appear to be occupied by more electron-sparse tissues or cytoplasm.

Each retinal cell contains thin membrane folded to form an array of rhabdoms (Fig. 1E). The dendrites from the anterior pairs of retinal cells are directed dorsally within the central space of the reflector (Fig. 1A), and then run postero-ventrally with the posterior pairs of retinal cells to meet the ventral nerve cord. 


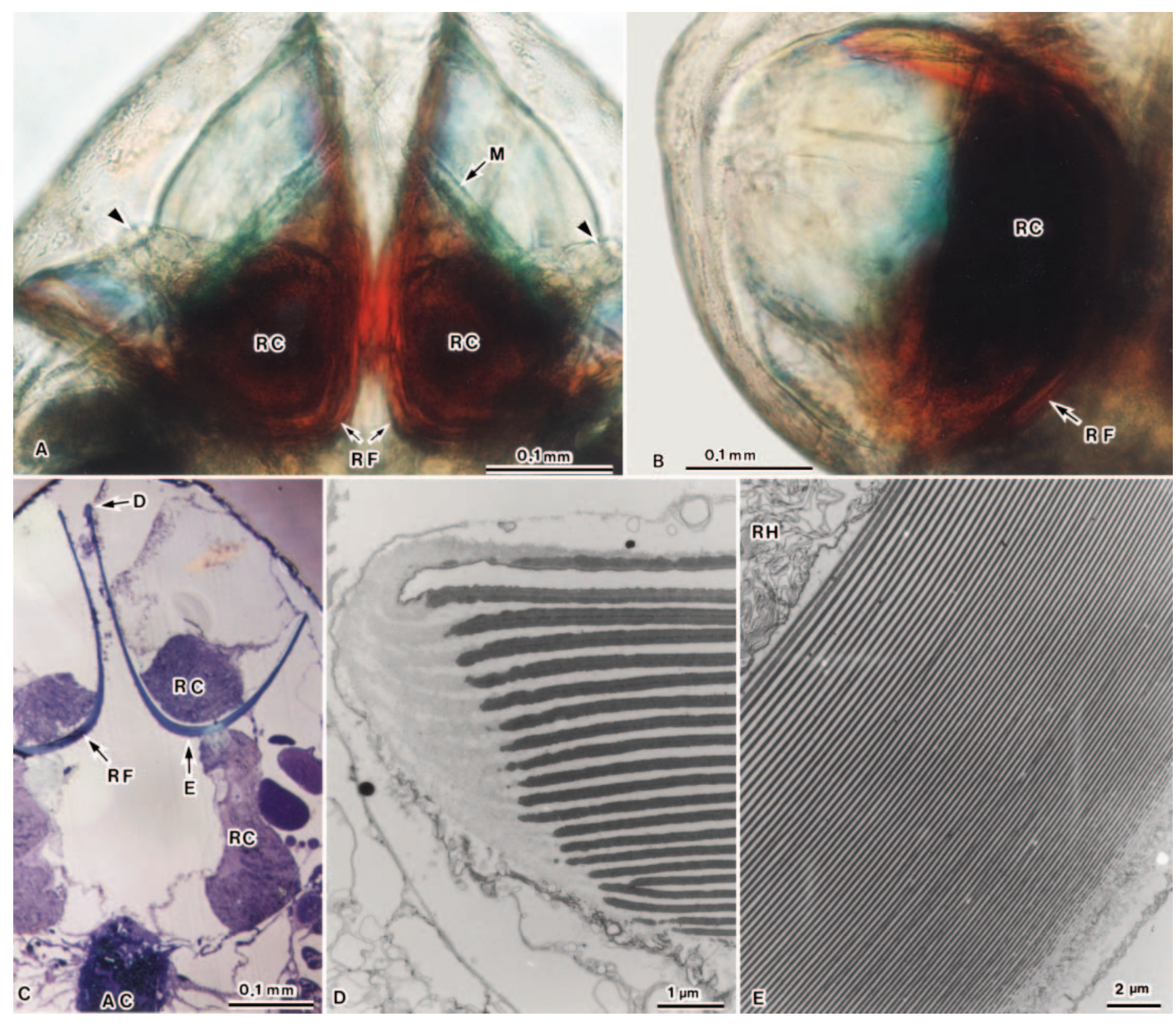

Fig. 1. Cephalophanes tectus $(\mathrm{A}, \mathrm{B})$ and C. refulgens $(\mathrm{C}-\mathrm{E})$ : eyes. (A) Dorsal view showing dorsal, concave margins of reflector along which retinal-cell dendrites (arrowheads) pass; (B) lateral view; (C) frontal section showing reflectors with locations of sections in (D) and (E); (D) TEM of mid-anterior end of reflector; (E) TEM of posterior end of reflector. AC: anterior midgut caecum; M: muscle band; RC: retinal cells; RH: rhabdom; RF: reflector

Viewed in transmitted light, the reflector either iridesces in a dark blue or a dark red colour, or appears semi-transparent with varying angles of the reflector (Fig. 1A). From the anterior side the central area appears almost opaque, but is more transparent peripherally. Viewed in reflected light, the reflector appears silvery with a faint pearly iridescence; the structure appears more reflective from the anterior view.

The predicted reflectance profile for the reflector is shown in Fig. 2, which is modeled for the stack near the anterior end (total of 45 layers of high and low refractive indices) and that at the posterior end (147 layers), as shown in Fig. 1D and E, respectively. Near the anterior end the reflectance over the 'animal visual' range of wavelengths (ca. 350 to $700 \mathrm{~nm}$ ) averages around $20 \%$ at angles of 0 to $50^{\circ}$ to the surface normal (perpendicular) (Fig. 2A), increasing to about 30\% at 60 to $70^{\circ}$; at $78^{\circ}$ the reflectance rapidly increases from around $50 \%$, as the angle of reflection approaches $90^{\circ}$ to the surface normal. It is an excellent reflector from 


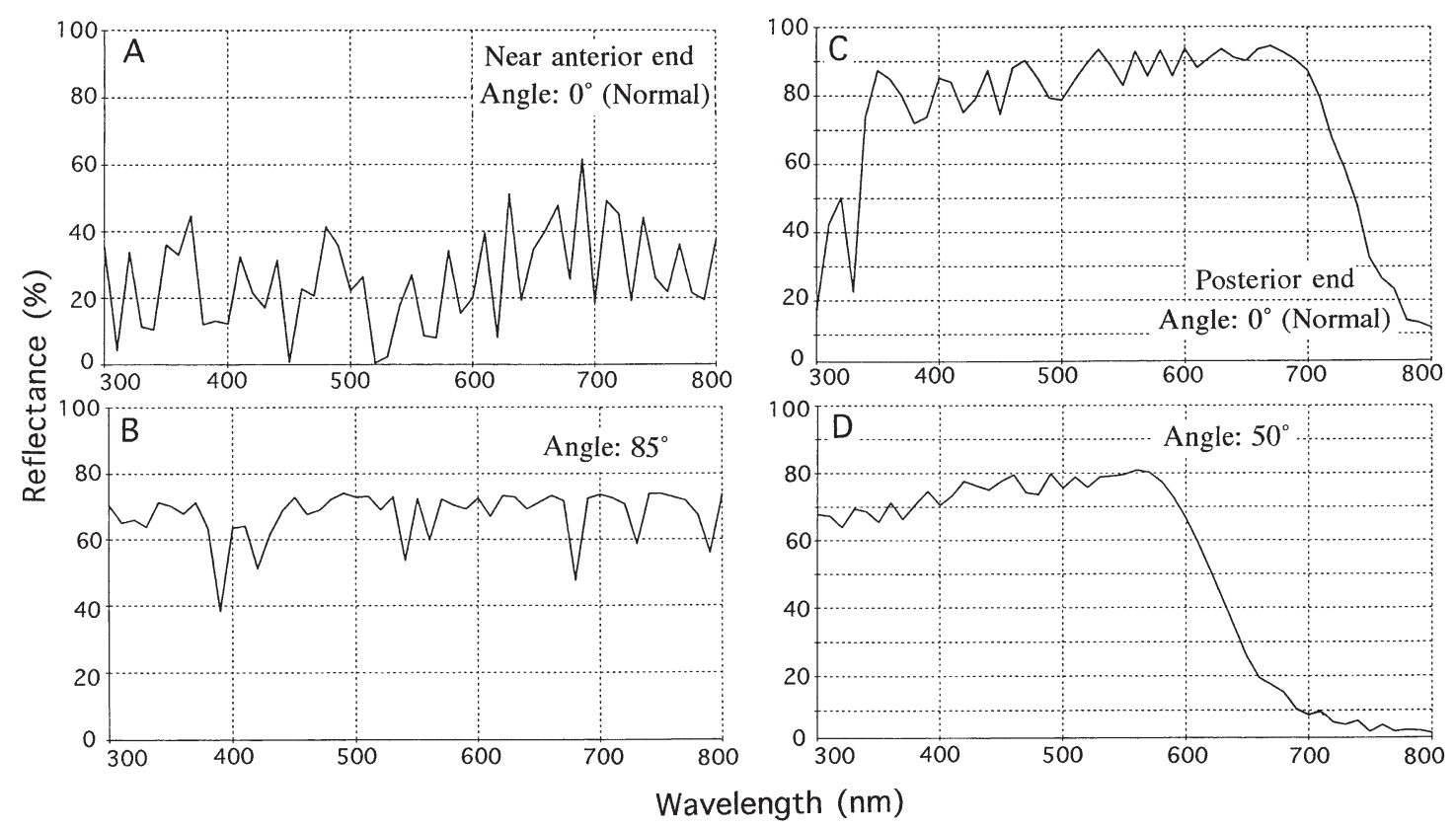

Fig. 2. Cephalophanes refulgens. Reflectance-wavelength graph for eye reflector calculated by the matrix method (Macleod 1969). Spectra for incidence at 2 representative angles are shown for the stack near anterior end $(A, B)$ and posterior end $(C, D)$

80 to $85^{\circ}$ (Fig. 2B). At the posterior end of the reflector, the reflectance over the 'animal visual' range of wavelengths averages around $85 \%$ at the surface normal (Fig. 2C). This reflection gradually decreases with departure from the normal, although it is still highly reflective at angles of 10 to $50^{\circ}$ to the surface normal, except that here the red wavelengths become increasingly transmitted rather than reflected (Fig. 2D) and the reflector becomes inefficient as a broadband reflector.

\section{Mouthpart appendages}

The gross morphology of the mouthpart appendages in the females of Cephalophanes spp. has been described in the taxonomic literature (Park 1983b, Tanaka \& Omori 1992 and references therein), and only the fine structures that are assumed to be functionally relevant in food manipulation are given here. The distal margin of the mandible gnathobase is armed (going from the ventral to the dorsal side) with 4 subequal tricuspidate teeth, 1 much smaller cuspidate tooth, 3 flat setae with grain-like surface and setules, and 1 longer seta with setules (Fig. 3A-C). The tricuspidate teeth are flat, with a thin margin, forming a parallel row of blades (Fig. 3B). The distal margin of the praecoxal arthrite of the maxillule has rows of slender setae with short setules (Fig. 3D). The setae from the endites of the maxilla are moderately long and slender, with short, sparse setules (Fig. 3E). The endo- pod bear 1 worm-like and 7 brush-like subequal setae, which are much shorter (ca. one-fifth) than the other, more proximal, setae (Fig. 3F). On the coxal endite of the maxilliped there is a brush-like seta medially (Fig. 3G). The other setae from endites and endopods are relatively short, with short sparse setules that modify terminally into teeth-like plates (Fig. $3 \mathrm{H}$ ).

\section{Midgut epithelium}

The gross morphology of the midgut of Cephalophanes spp. is divided into 3 distinct zones which are equally apparent in both $C$. refulgens and $C$. tectus and in all Stage CIV to CVI specimens: the anterior caecum, the mid zone, and the posterior zone (Fig. 4A-C). The anterior caecum is distinguishable from the mid zone by a marked constriction of varying degree, while the posterior zone is distinguishable by a reduced diameter and much reduced cellular oil inclusion compared to the mid zone (Fig. 4B-D).

The anterior caecum varies markedly in size and shape, ranging from very small, almost spherical caeca (Fig. 4D) to large and pear-shaped caeca, the latter always containing an ACB in the lumen (Fig. 4A,B,E, F; see also the following subsection). The epithelium consists exclusively of R (resorptive)-cells (Fig. 5A; see Arnaud et al. 1978 and Boxshall 1992 for definition of cell types) characterized by long microvilli, apically concentrated mitochondria, many oil droplets, and wellinvaginated plasma membrane at the base. The epi- 


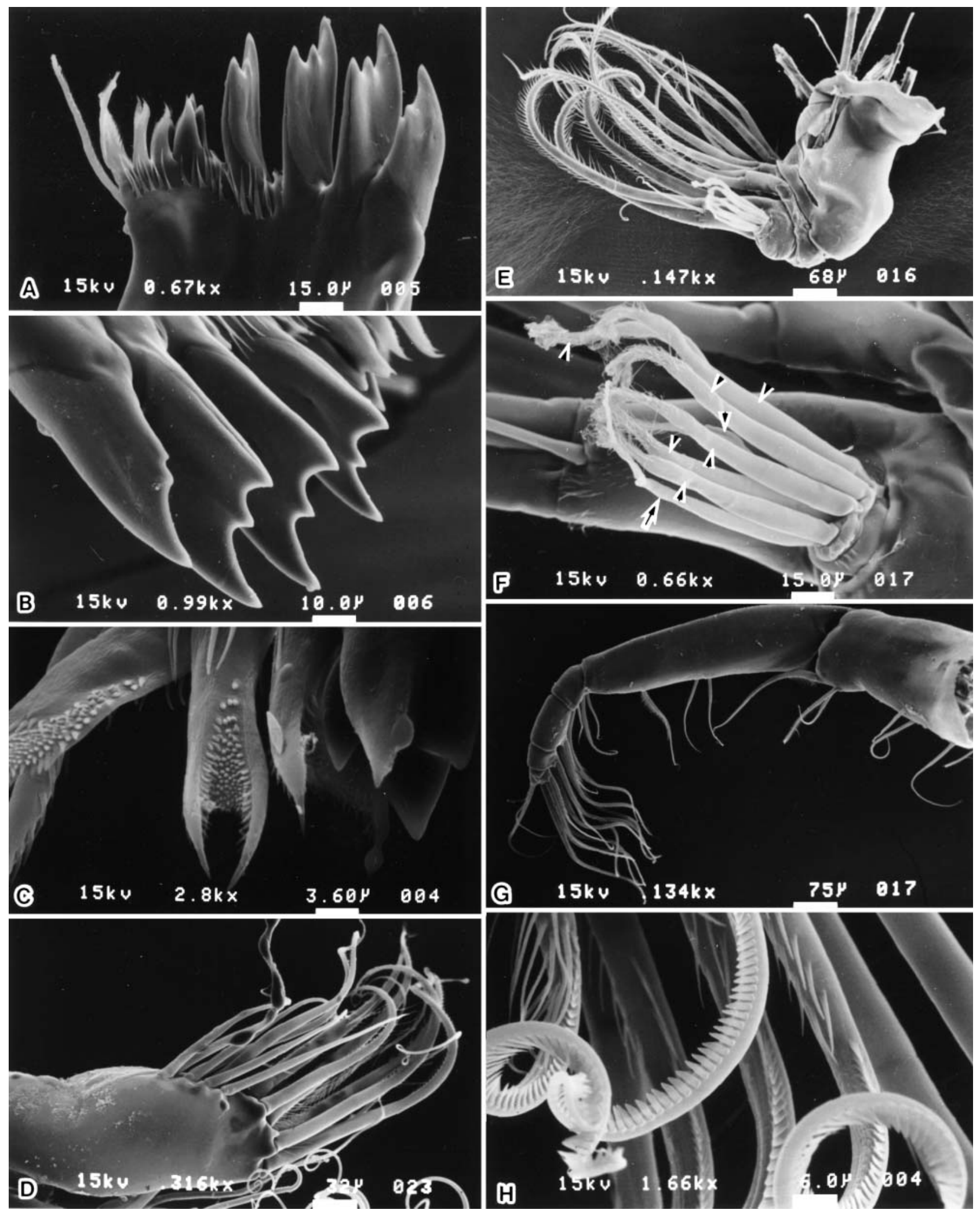

Fig. 3. Cephalophanes refulgens $(\mathrm{A}-\mathrm{F})$ and $C$. tectus $(\mathrm{G}, \mathrm{H})$ : mouthpart appendages. (A-C) Mandible gnathobase from different angles; (D) maxillule; (E) maxilla; (F) endopod of maxilla with 7 brush-like (arrowheads) and 1 worm-like (arrow) sensory setae; (G) maxilliped; (H) modified setules on maxilliped setae 


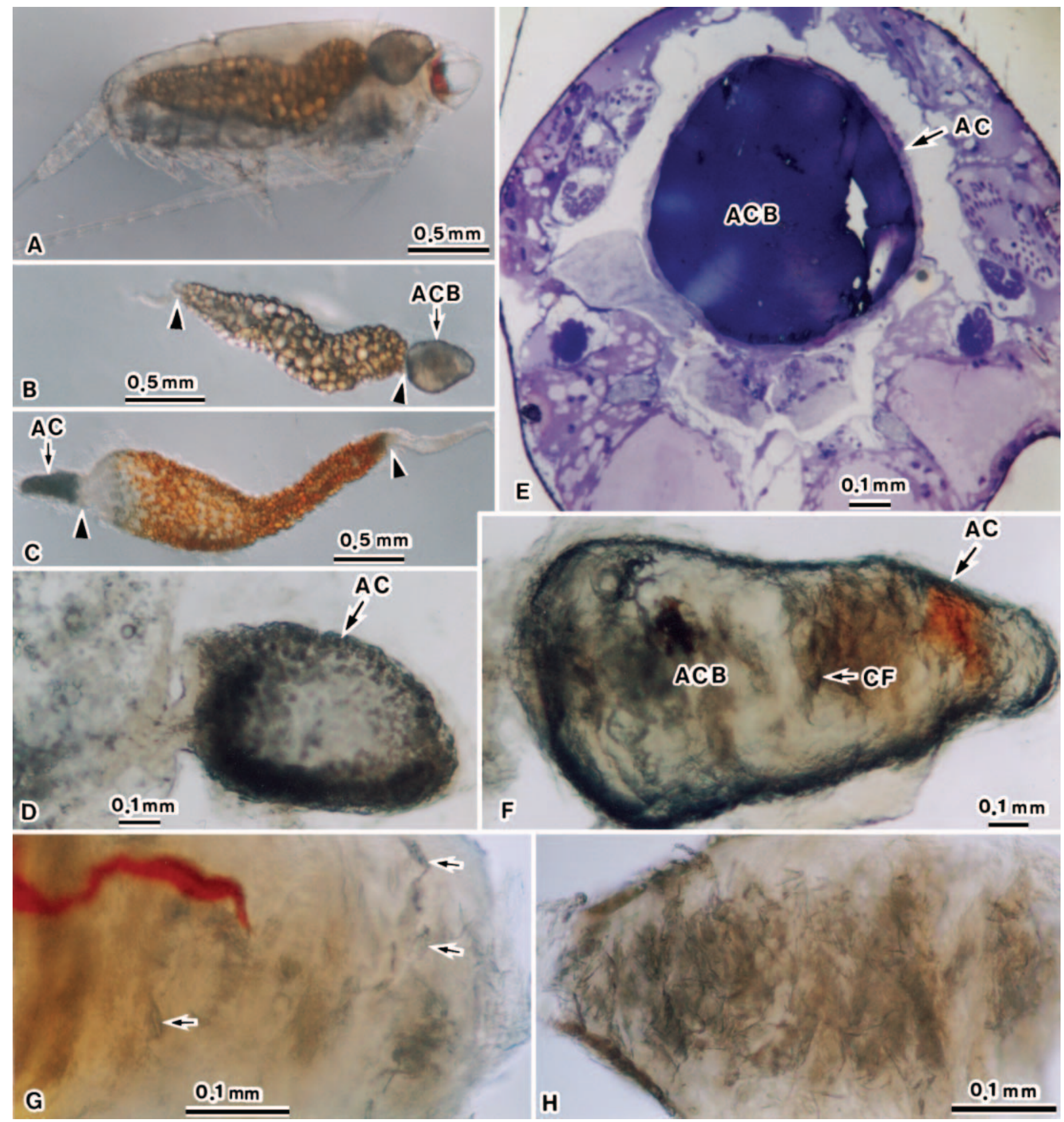

Fig. 4. Cephalophanes refulgens (A,B,D-H) and C. tectus (C): midgut and anterior caecum. (A) Intact copepod possessing an anterior-caecum body (ACB); (B) midgut removed from the specimen in (A), anterior side to the right (note distinct anterior caecum, mid zone with lipid inclusions, and posterior zone; boundaries of zones are shown: arrowheads); (C) midgut removed from a copepod without an ACB, anterior side to the left, showing boundaries of zones (arrowheads); (D) empty anterior caecum of another specimen of $C$. refulgens; (E) cross-section of cephalosome containing a fully developed $A C B$; $(F)$ anterior caecum with a fully developed, 'hard' $A C B$; $(G)$ 'moderately hard' $A C B$ containing red pigment and crustacean fragments (arrows); $(\mathrm{H})$ 'soft' $\mathrm{ACB}$ containing many crustacean fragments. AC: anterior caecum; $\mathrm{ACB}$ : anterior caecum body; CF: crustacean fragments 

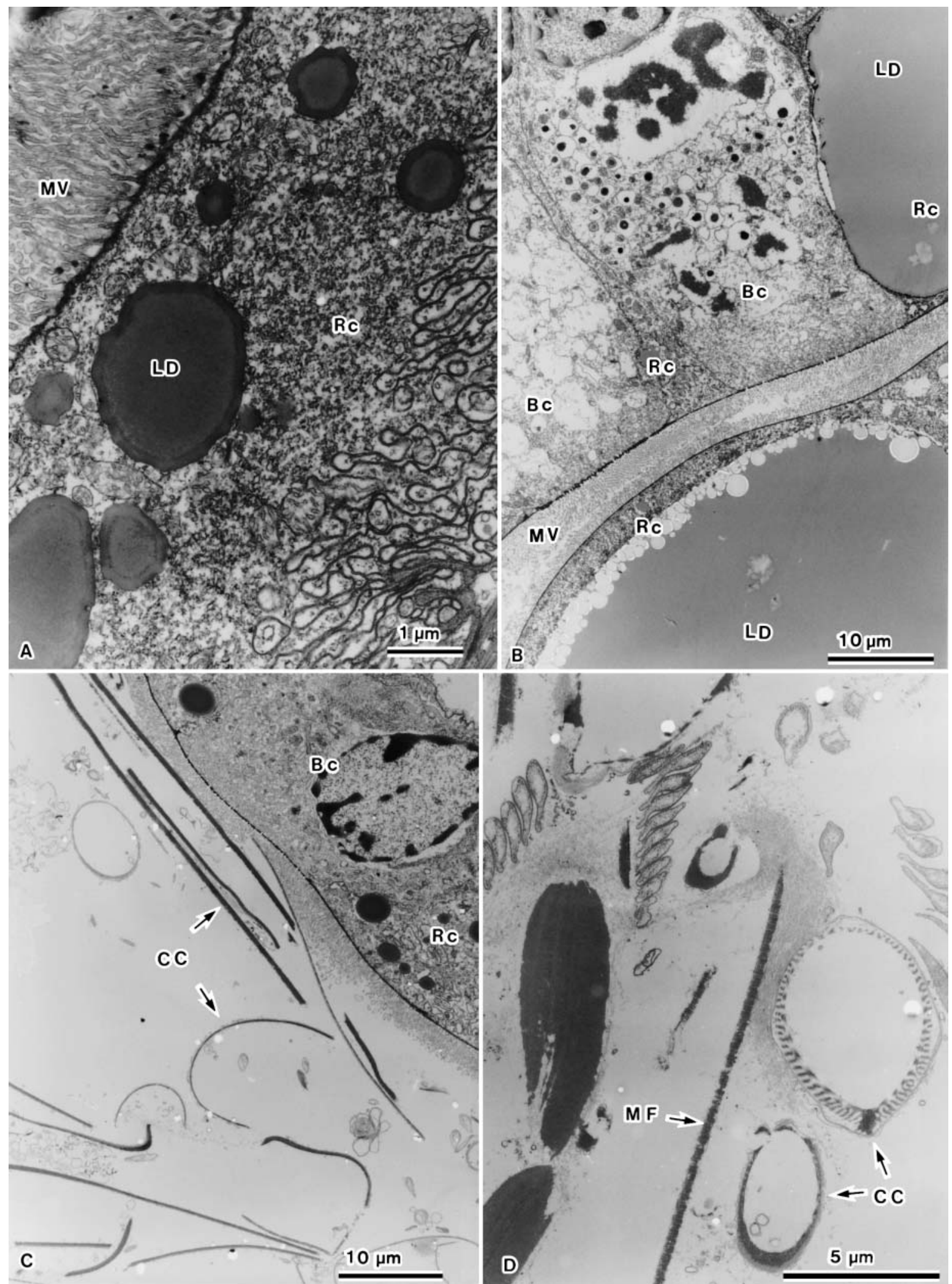

Fig. 5. Cephalophanes refulgens. TEM of midgut epithelium and contents. (A) R-cell in anterior caecum with ACB; (B) R- and B-cells in mid zone; (C) R- and B-cells and luminal contents in mid zone; (D) midgut contents of another individual. Bc: B-cell; CC: crustacean cuticle; LD: lipid drop; MF: muscle fiber; MV: microvilli; Rc: R-cell 
thelium of anterior caeca with a well-developed ACB in the lumen (Fig. 4E) tends to be much thinner than in those without an ACB.

The epithelium in the mid zone consists exclusively of B (blister-like)- and R-cells (Fig. 5B). The B-cells are characterized by apical microvilli, pinocytotic apical invaginations, vesicles of varying size, and a basally located nucleus. The R-cells have apical microvilli, apically concentrated mitochondria, and lipid drops that are either scattered over the cell or occur in the form of a single large inclusion occupying almost the whole cell area (Fig. 5B). The oil drops are very large in most specimens and clearly seen under the LM as spherical bodies surrounding the midgut lumen (Fig. 4B,C).

\section{Anterior-caecum body}

The term 'anterior-caecum body' (ACB) refers to the pear-shaped mass of unknown material in the lumen of the anterior midgut caecum (see 'Materials and methods'). The ACBs from specimens fixed in glutaraldehyde-formaldehyde ranged widely in size and shape (Table 2, Fig. 4B,F-H), hardness, color, and transparency with a tendency for larger ACBs to have a higher length/diameter ratio and to be harder and more transparent than smaller ones. In the hardest ACBs the tissue is semi-transparent, like a crystal (Fig. 4F), and does not distort under strong pressure from steel forceps. A large ACB often occupies a space dorsal to the eye reflectors, displacing these ventrally from their normal position. In ACBs of medial hardness (Fig. 4G), the tissue is more opaque, rubber-like, and easily distorted by light pressure from forceps, but quickly resumes its original shape. In the softest ACBs (Fig. 4H), the tissue is even more opaque, softer and jelly-like, and easily fragmented with a dissecting needle. Some ACBs, apart from their hardness, contain red pigments of unknown origin (Fig. 4F,G). All ACBs examined contained fragments of crustacean cuticle with a tendency for these to be more sparse in harder ACBs (Fig. 4F-H).
Treatment of a large, hard ACB with acetone or heated $\mathrm{HCl}$ did not affect its hardness, whereas an $\mathrm{ACB}$ treated with heated $\mathrm{KOH}$ for $2 \mathrm{~h}$ became fragile and was easily broken into pieces in which fragments of crustacean cuticle were apparent. The unfixed but frozen-thawed ACB was soft and opaque and contained crustacean fragments. This ACB was subsequently preserved in glutaraldehyde-formaldehyde for $4 \mathrm{~d}$, but there was no apparent change in its size, hardness or transparency, indicating that the present fixation/ preservation had not altered the physical, macrostructure of the ACBs. The 2 hard ACBs whose surfaces were examined for elemental composition showed high to moderate values of carbon (64.0\%), oxygen $(33.0 \%)$, and nitrogen $(2.4 \%)$ and trace values of phosphorus, sulfur, and chlorine (all $<0.5 \%$ ), other elements being under detection limits. These observations indicate that the ACBs primarily consist of organic compounds other than lipids and do not contain appreciable quantities of any characteristic metals or heavier elements.

\section{Midgut contents}

The lumen of the mid part of the midgut of 28 out of the 101 specimens examined contained fragments of crustacean cuticle that generally filled the lumen but were present only in trace amounts in some specimens, much sparser muscle tissues, oil droplets (see below), and unidentified, amorphous particles (Fig. 5C,D). Of these 28 specimens, 25 had an ACB in their midgut anterior caecum. Only 2 out of the 27 specimens which had an ACB had an empty midgut (Table 1). Phytoplankton, protista, or other nanoplankton including bacteria were not detected by closer examination with the TEM ( $\mathrm{n}=18$, including 5 specimens with luminal crustacean fragments) or SEM ( $\mathrm{n}=4$, all with luminal crustacean fragments) except for an intact frustule of a small pennate diatom from 1 specimen examined in the SEM. Oil droplets were found in the midgut lumen of 5 specimens in intact, SEM images or TEM sections,

Table 2. Cephalophanes spp. Size and proportions of 'anterior-caecum body'. Values are ranges (means)

\begin{tabular}{|lccccc|}
\hline Species/stage & $\mathrm{n}$ & $\begin{array}{c}\text { Length } \\
(\mathrm{mm})\end{array}$ & $\begin{array}{c}\text { Diameter } \\
(\mathrm{mm})\end{array}$ & $\begin{array}{c}\text { Length/diameter } \\
\text { ratio }\end{array}$ & $\begin{array}{c}\text { Length to } \\
\text { prosome ratio }(\%)\end{array}$ \\
\hline $\begin{array}{l}\text { C. refulgens } \\
\text { adult female }\end{array}$ & 4 & $0.65-1.30(0.94)$ & $0.40-0.70(0.55)$ & $1.5-1.9(1.7)$ & $15-30(31)$ \\
$\begin{array}{l}C \text {. tectus } \\
\text { adult female }\end{array}$ & 3 & $0.75-0.90(0.75)$ & $0.35-0.45(0.40)$ & $1.5-2.6(1.9)$ & $18-26(22)$ \\
$\begin{array}{l}\text { Copepodid } \\
\text { IV and V }\end{array}$ & 4 & $0.50-0.65(0.55)$ & $0.28-0.37(0.31)$ & $1.7-2.0(1.8)$ & $19-25(21)$ \\
\hline
\end{tabular}


but the possibility of their originating from the midgut epithelial cells cannot be ruled out, since epithelial cells are very fragile and intra-cellular oil droplets could have been extruded into the lumen during manipulation of the specimens.

Most crustacean fragments in the midgut lumen were too small to determine their origin; the only identifiable fragments were from copepods, including segments, setae/spines and intercoxal plates of swimming legs and other appendages, mandibular teeth, etc.

\section{DISCUSSION}

\section{Optic system}

The optic system of Cephalophanes spp. is highly characteristic among crustaceans in that it involves a pair of semi-parabolic reflectors which consist of alternate thin layers of, possibly, chitin and cytoplasm that gradually decrease in thickness in an inner-outer direction. A semi-parabolic reflector is also known from the eyes of the deep-sea ostracod Gigantocypris spp. (Land 1978), but its ultrastructure is not known. While the structure of chitinous layers of progressively decreasing thickness, termed a 'chirped' stack (Ouellette et al. 1995), has been reported from beetles (Neville 1977, Parker et al. 1998) and an amphipod (Parker 1999), the stack in Cephalophanes spp. has a greater number of total (light and dark) layers (ca. 150 vs ca. 80 in the beetles and the amphipod). Its silvery reflection under normally incidental white light is consistent with the reflectance spectrum modeled from its structure, indicating that the reflector is most efficient with an incident ray parallel to its axis. A chirped stack can be envisaged as a large number of sub-stacks, each consisting of a minimum of about 5 high-index layers (Parker 1999). Each sub-stack is tuned to reflect light at a wavelength in which the optical thickness of the layer (the product of the actual thickness and the refractive index) is approximately a quarter of a wavelength (the slight variation in thickness of the highindex layers within a sub-stack does not significantly affect the optical efficiency).

It is interesting that the reflector of Cephalophanes spp. is highly efficient (almost perfect) for reflecting the complete range of wavelengths from 350 to $700 \mathrm{~nm}$ (and this range only) toward the focal point of the reflective structure only when the light source is incident and originating anterior to the copepod. Therefore Cephalophanes spp. have evolved to detect 'white' light from an anterior direction.

According to Land $(1978,1984)$ and Nilsson (1996) the concave mirror eyes of Gigantocypris spp. have an $f$-number of 0.25 , which is very low compared to those of other types of eyes, e.g. lens eyes in dark-adapted humans ( $f=2)$ and fishes $(f=1.25)$, superposition-type compound eyes in mesopelagic shrimps $(f=0.5)$, and apposition-type compound eyes in diurnal insects $(f=$ 2.4). Since image brightness is proportional to $1 / f^{2}$, the retinal image in Gigantocypris spp. is 64 times brighter than in a dark-adapted human eye (Nilsson 1996) and 17 times brighter than in a fish eye (Land 1978) viewing the same scene. The vertically oriented retinal cells in Gigantocypris spp. are in the focal area of the semiparabolic reflector, so that they efficiently capture a large proportion of the reflected light (Land 1978). These properties also apply to the eyes of Cephalophanes spp., which have the same macrostructure as the eyes of Gigantocypris spp. (see Boxshall 1992). On the basis of these macrostructure attributes, the high reflectivity (averaging ca. $85 \%$ ) of the multilayered reflector over a wide range of wavelengths (350 to $700 \mathrm{~nm}$ ), the retinal cells with well-developed rhabdoms, and the muscle band attached to the reflector (which we assume functions in controlling the reflector direction), the eye of Cephalophanes spp. is considered one of the most effective broadband, directionallight detectors among animals, while its resolution may be poor due to the small number of retinal cells (see also Land 1978, Boxshall 1992). With regard to the 2 pairs of retinal cells posterior to the reflectors, we have no plausible explanation for their function.

\section{Mouthpart appendages}

On the basis of the present observations and morphological information in the taxonomic literature, the characteristics of female mouthpart appendages in Cephalophanes spp. of functional relevance are summarized below. For convenience the term 'Bradfordian families' (Ferrari \& Markhaseva 1996) is used here to refer to families possessing specialized sensory setae (worm-like and brush-like setae: Nishida \& Ohtsuka 1997) on the maxilla and maxilliped (i.e. Scolecitrichidae, Phaennidae, Diaixidae, Tharybidae, and Parkiidae, of which the Scolecitrichidae, as a whole, are primarily mesopelagic and generalized detritivores/ omnivores: Harding 1974, Hopkins 1985, Gowing \& Wishner 1986, 1992, Nishida et al. 1991, Ohtsuka \& Kubo 1991). The other families are primarily benthopelagic, with species more or less skewed to specialized detritivory or carnivory (Gowing \& Wishner 1986, 1992, Ohtsuka et al. 2002, S.N. \& S.O. unpubl. data).

The mandible gnathobase in Cephalophanes spp. has relatively large, flat, blade-like teeth forming a parallel row, with the possible function of cutting rather than masticating food material into small pieces. A similar type of teeth is present in the species of 
Scolecitrichidae (e.g. Macandrewella, Scaphocalanus, Scolecithricella, Racovitzanus; see figures in Ohtsuka et al. 2002, and Park 1980, 1982, 1983a, for comparison) and in Xanthocalanus (see figures in Grice \& Hulsemann 1970) but not in other genera of Phaennidae of known mandible morphology (Phaenna, Onchocalanus and Cornucalanus), in which the respective teeth are finer, more or less conical, and/or have more complex morphology (see Park 1983b).

The setae from the coxal endites of the maxillule, the endites of the maxilla, and the endites and endopods of the maxilliped are moderately slender, with short sparse setules, and lack marked setal specialization such as strong spines and setae with highly modified setules, suggesting the capture and manipulation of relatively large inactive particles.

There are 7 brush-like and 1 worm-like setae on the endopod of the maxilla, a major diagnostic character of the Phaennidae, and both types of setae are shorter and more slender than in other Bradfordian families, a characteristic shared by the phaennid genera. Other Bradfordian families typically have 3 worm-like and 5 brush-like setae on the endopod and 2 additional worm-like setae on the basal endite (Bradford 1973, Bradford et al. 1983, Ferrari \& Markhaseva 1996), with well-developed worm-like setae, often of comparable size to the ordinary setae. Both types of setae have ultrastructures representing chemoreceptors and are assumed to function in the chemical detection of detrital particles (Nishida \& Ohtsuka 1997), whereby the worm-like setae may be involved in relatively far-field detection and the brush-like setae in near-field detection. The reduction and increase in numbers of wormlike and brush-like setae, respectively, and the reduction in the size of both types of setae in the Phaennidae suggest that this group has deviated from general detritivory by exploiting other foraging tactics as alternatives to the use of chemical signals, particularly in far-field food detection.

\section{Midgut structure and contents}

Many copepods have an anterior midgut caecum which is an extension of the midgut anterior to the esophagus (Boxshall 1982). The anterior caecum of Cephalophanes spp. differs from those in most copepods in that it is distinctly separated from the more posterior part of the midgut by a marked constriction and that it often contains an anterior-caecum body (ACB) in the lumen. A similarly distinct anterior caecum is known in harpacticoids (Sullivan \& Bisalputra 1980 ) and the bathypelagic copepod genus Benthomisophria (Boxshall 1982), the latter having a caecum which can be completely closed off by a muscular valve, but possession of an $\mathrm{ACB}$, to our knowledge, is unique to Cephalophanes spp. among the Crustacea.

Among the cell types known from the midguts of copepods (F-, D-, B-, and R-cells: see Boxshall 1992), only B- and R-cells were present in Cephalophanes spp., and the R-cells contained many lipid inclusions, either in the form of small droplets or as large drops occupying almost the whole lumen of the cell, the latter being particularly apparent in the middle region. While the R-cells with lipid inclusions are known in copepods, as in calanoids (Arnaud et al. 1980, Nishida et al. 1991), poecilostomatoids (Briggs 1977) and harpacticoids (Sullivan \& Bisalputra 1980, Yoshikoshi 1980), the large amount of lipids seen in Cephalophanes spp. appears to be more or less limited to particular groups such as some deep-sea copepods (S.N. unpubl. obs.). While oil sacs are common lipidstorage sites in calanoid copepods and can be large in particular species (Blades-Eckelbarger 1991, see Mauchline 1998 for review), only a small amount of stored lipid was found in Cephalophanes spp. in a region ventral to the anterior caecum (S.N. unpubl. obs.), except for the gut-epithelium inclusions, suggesting that the gut epithelial cells are major lipidstorage sites in the genus Cephalophanes.

The midgut contents of Cephalophanes spp. consisted exclusively of fragments of crustacean cuticle, often associated with a minor amount of muscle fibers and amorphous particles, presumably originating from food organisms, suggesting that their major food consists of crustacean carcasses and (less importantly) molts. The absence of typical 'marine snow signatures' (Lampitt et al. 1993), i.e. materials from phytoplankton, protista, and other pico- and nanoplankters, from the midgut contents precludes other types of marine snow as possible foods. Feeding on live crustaceans is also unlikely, since the maxilla and maxillipeds of Cephalophanes spp. are relatively slender, and body tissues other than cuticular fragments were minor components of the midgut contents.

With the absence of knowledge about the biochemical properties of the $\mathrm{ACB}$, the functions of the anterior caecum and the ACB are also unknown. However, the inclusion of cuticular fragments within the $\mathrm{ACB}$, the decrease in the amount of fragments in more welldeveloped ACBs, and the high coincidence of the ACB with luminal cuticular fragments in the mid part of the midgut suggest a role of the ACB in chitin digestion.

\section{Possible feeding mechanism}

On the basis of available information, either on the functional morphology and ecology of Cephalophanes spp. or on the deep-sea environment in general, hy- 
potheses on the ecological role of the eye in Cephalophanes spp. are proposed and tested below.

First we examine the relevance of the 3 major behavioral categories of selective significance in animals: mate-finding, predator avoidance, and feeding. Among these categories, use of the eye in mate-finding is most unlikely. If the eyes are to function in matefinding in the deep sea, these will work most effectively by sensing the luminescence from conspecific mates, but no luminescent species has been reported in Cephalophanes or other related genera (see review by Mauchline 1998, his Table 69), and the eye structure of the adult is similar to those of immature copepodids. Antipredation behavior can also be eliminated as a major selective force, since the luminescence strategies of possible predators of Cephalophanes spp., such as fishes, squids, euphausiids, decapods, cnidarians and predatory copepods, comprise either flashlights, counter-illumination of dim light, or continuous light for luring prey (see Young 1983, Herring 2000, and references therein); sensing of light would not appear to be advantageous in locating predators in these cases. Moreover, a highly reflective eye might constitute a light source for predators, and thus could even be a negative selective force in terms of predator avoidance. Thus, feeding is the most probable factor that might have exerted a major selective force on the development of the eye, wherein targeted foods must be luminescent and without high motility for effective capture. The following questions arise: On what precisely do Cephalophanes spp. feed? How do Cephalophanes spp. employ vision during feeding? Do their eyes work in tandem with other receptors, forming a multimodal sensory system for food detection?

In addition to the unique characteristics of the optic, feeding, and digestive systems in Cephalophanes spp. described in the previous sections, the following pieces of circumstantial evidence are available on their food environment and ecology: Luminous bacteria are known from crustacean and fish carcasses (Wada et al. 1995). These bacteria produce 'continuous' luminescence lasting for hours (Nealson \& Hastings 1979, Haas 1980, Andrews et al. 1984, Wada et al. 1995), which is a prerequisite for the efficient tracing and capture of a targeted light source, whereas most luminous animals generally produce erratic flashes with durations of tens (or hundreds) of milliseconds (Andrews et al. 1984). It has also been reported that Photobacterium phosphoreum, a major luminous bacterium in deep waters, has its population peak below $200 \mathrm{~m}$ depth in the North Atlantic (Ruby et al. 1980), which coincides with the known distributional depths of Cephalophanes spp., i.e. meso- and bathypelagic zones (Steuer 1928, Wiebe et al. 1988, S.N. unpubl. data). On the other hand, copepod carcasses, a presumed food-source for $\mathrm{Ce}$ - phalophanes spp., have been reported frequently from various waters of the world, including meso- and bathypelagic zones, with high abundances in some cases (e.g. Farran 1926, Weikert 1977, Terazaki \& Wada 1988, Genin et al. 1995, Haury et al. 1995). Thus they are among the most ubiquitous, if not most abundant, immobile organic particles suspended in the water column in the deep sea.

On the basis of these observations, the previous hypothesis by Steuer (1928), that the eyes of Cephalophanes spp. detect the direction of light and that the 'rain of carcasses' is a primary food source, may be elaborated as follows: These copepods detect the bioluminescence of bacteria associated with crustacean carcasses and, presumably with the aid of the sensory setae on their maxilla and maxilliped, capture and manipulate the carcasses with mouthpart appendages bearing slender and sparsely setulose setae, transporting them into the preoral food chamber. The carcasses are then chopped into small pieces with the razor-like mandibular teeth and ingested. The ingested food, comprising chitinous fragments and a lesser amount of other body tissues, are then digested and absorbed by the combined functions of the specialized midgut anterior caecum, middle zone epithelium, and the $\mathrm{ACB}$ through a so far unknown process.

While all the above-mentioned observations are consistent with this hypothesis, there are some observations that appear inconsistent. First, the eye-reflectors are adapted to wavelengths of 350 to $700 \mathrm{~nm}$, with high (80 to $90 \%)$ reflectivity throughout the range, whereas in the mesopelagic zone most luminescence has spectral peaks within a much narrower range $(400$ to $500 \mathrm{~nm}$ ), including that of luminous bacteria (Herring 1983, Widder et al. 1983, Haddock \& Case 1999). Also, in waters below ca. $200 \mathrm{~m}$ depth, i.e. the environment of Cephalophanes spp., the light is exclusively blue (Denton 1990). Possible explanations for this inconsistency between the wavelengths of light in the environment and the wavelengths that can be reflected include: (1) Utilization by Cephalophanes spp. of all available light, i.e. not only of light around peak wavelengths but also other minor wavelengths, over the whole spectrum. (2) Extinction of light sources with peaks of longer wavelengths $(>500 \mathrm{~nm})$ that were present at the first appearance of the reflector structure in the course of evolution; a lysianassoid amphipod (Crustacea), for example, is known to possess a reflector that reflects blue bioluminscence, whereby the reflector is broadband but has a strong peak reflectance in the blue region (Parker 1999). (3) The presence of an unknown luminescence with spectral peaks at longer wavelengths. Second, we have been unable to detect any abundance of bacteria in the midgut contents, either by TEM or SEM, and only a 
few bacteria were detected in a preliminary examination of 2 specimens stained with DAPI by epifluorescence microscopy (S.N. \& M. Wada unpubl. data). This low or negligible occurrence of bacteria in the midgut contents appears to be at odds with the bacterial numbers necessary to be detectable by animals $\left(10^{7}\right.$ or $10^{8}$ cells $\mathrm{ml}^{-1}$, roughly estimated on the basis of known bacterial emission and photoreceptor sensitivity: Nealson \& Hastings 1979). Possible explanations include (1) the higher sensitivity of the Cephalophanes spp. eye relative to the sensitivity of animals assumed as above, (2) the rapid digestion of bacteria in the midgut lumen, and (3) the small sample size in the present study. Third, the midgut contents were composed exclusively of crustacean fragments and devoid of the typical 'marine-snow signature', whereas luminous bacteria are known to occur in marine snow, faecal pellets, and in sediment-trap particles other than carcasses (Andrews et al. 1984), and some of these particles are assumed to have nutritional values similar to or even higher than that of carcasses (e.g. Alldredge \& Silver 1988, Lampitt et al. 1993). A possible explanation for this presumed specificity for carcasses is a difference in the bacterial flora between carcasses and other particles that could result in different optical effects among particles, but our knowledge is insufficient to pursue this subject further. Finally, more interesting than contradictory, Gigantocypris muelleri, an ostracod with an eye of the same macrostructure as that of Cephalophanes spp., is known to be a generalized carnivore on the basis of stomach-contents analysis and behavioral observation (Moguilevsky \& Gooday 1977), which may indicate the use of the same optic system for markedly different feeding tactics. In addition, a recent study revealed another possible example of coupling optical and feeding systems. Scolecitrichid copepods of the genus Macandrewella possess a lens-eye, and they have been found with their midguts filled with crustacean fragments (Ohtsuka et al. 2002). Species of this genus live in near-bottom layers at ca. >100 m depth, suggesting a parallelism in the evolution of specialized detritivory.

There is another possibility that Cephalophanes spp. feed on slow-moving luminescent copepods at depth. However, this is much less likely, since tissues other than chitinous fragments and detritus were minor constituents of their gut contents, and known copepod luminescence is typified by flashing rather than by continuous light, and thus would provide poor targets for a visual predator.

In summary, compared with the total species diversity in the Bradfordian families, encompassing ca. 300 species, the genus Cephalophanes, with only 3 species, is among the most minor of subgroups in terms of both diversity and biomass. Thus it may utilize nutri- tionally poor but constantly available foods that are not utilizable by other copepods, representing an extreme feeding specialization in the resource-limited deep sea. While still more observations are necessary, the hypothesis, we believe, will contribute to our understanding of the species diversity and resource-partitioning in the pelagic ecosystem. Further study will include the abundance, floral composition and activity of bacteria on crustacean carcasses and marine snow and in gut contents, and the biochemical characteristics of the ACB, the intracellular lipids, and digestive enzymes of Cephalophanes spp.

Acknowledgements. We thank the captain and crew members of the TRV 'Toyoshio Maru' and the RVs 'Hakuho Maru' and 'Tansei Maru' for their cooperation in sampling at sea. Special thanks are due to Dr R. Böttger-Schnack for translating German literature and to Dr A. Reich for assisting in the translation of a French text paragraph. Thanks are also due to Dr M. Wada for discussion and information on luminous bacteria, and to Dr N. Ikeya for literature information on Gigantocypris spp. This study has been supported by a Grantin-Aid for Scientific Research (No. 10660180) and a Grant-inAid for Creative Basic Research (No. 12NP0201) from the Ministry of Education, Science, Arts and Sports of Japan.

\section{LITERATURE CITED}

Alldredge AL, Silver MW (1988) Characteristics, dynamics and significance of marine snow. Prog Oceanogr 20:41-82

Andrews CC, Karl DM, Small LF, Fowler SW (1984) Metabolic activity and bioluminescence of oceanic faecal pellets and sediment trap particles. Nature 307:539-541

Arnaud J, Brunet M, Mazza J (1978) Studies on the midgut of Centropages typicus (copepod, calanoid). 1. Structural and ultra-structural data. Cell Tissue Res 187:333-353

Arnaud J, Brunet M, Mazza J (1980) Structure et ultrastructure comparées de l'intestin chez plusieurs espèces de Copépodes Calanoides (Crustacea). Zoomorphologie 95: 213-233

Blades-Eckelbarger PI (1991) Comparative ultrastructure of lipid storage sites in female Euchaeta marina and Pleuromamma xiphias (Copepoda: Calanoida). Mar Biol 108: 49-58

Boxshall GA (1982) On the anatomy of the misophrioid copepods, with special reference to Benthomisophria palliata Sars. Phil Trans R Soc Lond Biol Sci 297:125-181

Boxshall GA (1985) The comparative anatomy of two copepods, a predatory calanoid and a particle-feeding mormonilloid. Phil Trans R Soc Lond Biol Sci 311:303-377

Boxshall GA (1992) Copepoda. In: Harrison FW, Humes AG (eds) Microscopic anatomy of invertebrates, Vol 9. Crustacea. Wiley-Liss Inc, New York, p 347-384

Bradford JM (1973) Revision of family and some generic definitions in the Phaennidae and Scolecithricidae (Copepoda: Calanoida). NZ J Mar Freshw Res 7:133-152

Bradford JM, Haakonssen L, Jillett J (1983) The marine fauna of New Zealand: pelagic calanoid copepods: families Euchaetidae, Phaennidae, Scolecithricidae, Diaixidae, and Tharybidae. Mem NZ Oceanogr Inst 90:1-150

Briggs RP (1977) Structural observations on the alimentary canal of Paranthessius anemoniae, a copepod associate of 
the snakelocks anemone Anemonia sulcata. J Zool (Lond) 182:353-368

Cahoon LB (1982) The use of mucus in feeding by the copepod Euchirella venusta Giesbrecht. Crustaceana 43: 202-204

Chae J, Nishida S (1994) Integumental ultrastructure and color patterns in the iridescent copepods of the family Sapphirinidae (Copepoda: Poecilostomatoida). Mar Biol 119:205-210

Chae J, Kita-Tsukamoto K, Nishida S, Ohwada K (1996) Chemical composition of the integumental reflecting platelets in the iridescent copepods of the family Sapphirinidae (Poecilostomatoida). J Crustac Biol 16:20-23

Denton EJ (1990) Light and vision at depths greater than 200 meters. In: Herring PJ, Campbell AK, Whitfield M, Maddock L (eds) Light and life in the sea. Cambridge University Press, Cambridge, p 127-148

Farran GP (1926) Biscayan plankton collected during a cruise of HMS Research, 1990. Pt XIV. The Copepoda. J Linn Soc Lond Zool 36:219-310, pls 5-10

Ferrari FD, Markhaseva EL (1996) Parkius karenwishneri, a new genus and species of calanoid copepod (Parkiidae, new family) from benthopelagic waters of the eastern tropical Pacific Ocean. Proc Biol Soc Wash 109:268-285

Genin A, Gal G, Haury L (1995) Copepod carcasses in the ocean. II. Near coral reefs. Mar Ecol Prog Ser 123:65-71

Gowing MM, Wishner KF (1986) Trophic relationships of deep-sea calanoid copepods from the benthic boundary layer of the Santa Catalina Basin, California. Deep-Sea Res Part A Oceanogr Res Pap 33A:939-961

Gowing MM, Wishner KF (1992) Feeding ecology of benthopelagic zooplankton on an eastern tropical Pacific seamount. Mar Biol 112:451-467

Grice GD, Hulsemann K (1970) New species of bottom-living calanoid copepods collected in deepwater by the DSRV Alvin. Bull Mus Comp Zool 139:185-230

Haas E (1980) Bioluminescence from single bacterial cells exhibit no oscillation. Biophys J 31:301-312

Haddock SHD, Case JF (1999) Bioluminescence spectra of shallow and deep-sea gelatinous zooplankton: ctenophores, medusae and siphonophores. Mar Biol 133:571-582

Harding GCH (1974) The food of deep-sea copepods. J Mar Biol Assoc UK 54:141-155

Haury L, Fey C, Gal G, Hobday A, Genin A (1995) Copepod carcasses in the ocean. I. Over seamounts. Mar Ecol Prog Ser 123:57-63

Herring PJ (1983) The spectral characteristics of luminous marine organisms. Proc R Soc Lond Ser B Biol Sci 220: 183-217

Herring PJ (1994) Reflective systems in aquatic animals. Comp Biochem Physiol A 109:513-546

Herring PJ (2000) Bioluminescent signals and the role of reflectors. J Opt A 2:R29-R38

Hopkins TL (1985) Food web of an Antarctic midwater ecosystem. Mar Biol 89:197-212

Isaacs JB, Kidd LW (1953) Isaacs-Kidd midwater trawl. Scripps Inst Oceanogr Univ Calif, Ref 53-3, Oceanographic Equipment Report 1, p 1-21

Krishnaswamy S, Raymont JEG, Woodhouse MA, Griffin RL (1967) Studies on the fine structure of Copepoda. Observation on the fine structure of buttons on the setae of the maxilla and maxilliped of Centraugaptilus horridus (Farran). Deep-Sea Res 14:331-335

Lampitt RS, Wishner KF, Turley CM, Angel MV (1993) Marine snow studies in the Northeast Atlantic Ocean: distribution, composition and role as a food source for migrating plankton. Mar Biol 116:689-702
Land MF (1972) The physics and biology of animal reflectors. Prog Biophys Mol Biol 24:75-106

Land MF (1978) Animal eyes with mirror optics. Sci Am 239: $126-134$

Land MF (1984) Crustacea. In: Ali MA (ed) Photoreception and vision in invertebrates. Plenum Press, New York, p 401-438

Macleod HA (1969) Thin film optical filters. Adam Hilger, London

Matsuura H, Nishida S (2000) Fine structure of the 'button setae' in the deep-sea pelagic copepods of the genus Euaugaptilus (Calanoida: Augaptilidae). Mar Biol 137: 339-345

Mauchline J (1998) The biology of calanoid copepods. Adv Mar Biol 33:1-710

Moguilevsky A, Gooday AJ (1977) Some observations on the vertical distribution and stomach contents of Gigantocypris muelleri Skogsberg 1920 (Ostracoda, Myodocopina). In: Loffler H, Danielopol D (eds) Proceedings of the 6th International Symposium on Ostracods, Saalfelden, 1976. Dr W Junk, The Hague, p 263-270

Nealson KH, Hastings JW (1979) Bacterial bioluminescence: its control and ecological significance. Microbiol Rev 43: $496-518$

Neville AC (1977) Metallic gold and silver colours in some insect cuticles. J Insect Physiol 23:1267-1274

Nillson DE (1996) Eye design, vision and invisibility in planktonic invertebrates. In: Lenz PH, Hartline DK, Purcell JE, Macmillan DL (eds) Zooplankton: sensory ecology and physiology. Gordon \& Bearch Publ, Amsterdam, p 149-162

Nishida S, Ohtsuka S (1996) Specialized feeding mechanism in the pelagic copepod genus Heterorhabdus (Calanoida: Heterorhabdidae), with special reference to the mandibular tooth and labral glands. Mar Biol 126:619-632

Nishida S, Ohtsuka S (1997) Ultrastructure of the mouthpart sensory setae in mesopelagic copepods of the family Scolecitrichidae. Plankton Biol Ecol 44:81-90

Nishida S, Oh BC, Nemoto T (1991) Midgut structure and food habits of the mesopelagic copepods Lophothrix frontalis and Scottocalanus securifrons. Bull Plankton Soc Jpn Spec Vol:527-534

Ohtsuka S, Kubo N (1991) Larvaceans and their houses as important food for some pelagic copepods. Bull Plankton Soc Jpn Spec Vol:535-551

Ohtsuka S, Soh HY, Nishida S (1997) Evolutionary switching from suspension feeding to carnivory in the calanoid family Heterorhabdidae (Copepoda). J Crustac Biol 17: 577-595

Ohtsuka S, Nishida S, Nakaguchi K (2002) Three new species of the genus Macandrewella (Copepoda: Calanoida: Scolecitrichidae) from the Pacific Ocean, with notes on distribution and feeding habits. J Nat Hist (in press)

Omori M (1965) A 160-cm opening-closing plankton net. 1. Description of the gear. J Oceanogr Soc Jpn 21:212-220

Ouellette F, Krug PA, Stephens T, Dhosi G, Eggleton BJ (1995) Dispersion compensation using chirped sampled fibre Bragg gratings. Electronics Lett 31:899-901

Park T (1980) Calanoid copepods of the genus Scolecithricella from Antarctic and Subantarctic waters. Biology of Ant arctic seas IX. Antarct Res Ser 31:25-79

Park T (1982) Calanoid copepods of the genus Scaphocalanus from Antarctic and Subantarctic waters. Biology of Antarctic seas XI. Antarct Res Ser 34:75-127

Park T (1983a) Calanoid copepods of some scolecithricid genera from the Antarctic and Subantarctic waters. Biology of Antarctic seas XIII. Antarct Res Ser 38:165-213

Park T (1983b) Calanoid copepods of the family Phaennidae 
from Antarctic and Subantarctic waters. Biology of Antarctic seas XIV. Antarct Res Ser 39:317-368

Parker AR (1999) An unusually isolated reflector for host bioluminescence on the second antenna of a lysianassoid (Amphipoda, Gammaridea). In: Schram FR, von Vaupel Klein JC (eds) Crustaceans and the biodiversity crisis. Brill, Leiden, p 879-887

Parker AR, McKenzie DR, Large MCJ (1998) Multilayer reflectors in animals using green and gold beetles as contrasting examples. J Exp Biol 201:1307-1313

Ruby EG, Greenberg EP, Hastings JW (1980) Planktonic marine luminous bacteria: species distribution in the water column. Appl Environ Microbiol 39:302-306

Steinberg DK, Silver MW, Pilskaln CH, Coale SL, Paduan JB (1994) Midwater zooplankton communities on pelagic detritus (giant larvacean houses) in Monterey Bay, California. Limnol Oceanogr 39:1606-1620

Steuer A (1928) Ueber das sogenannte Leuchtorgan des Tiefsee-Copepoden Cephalophanes G.O. Sars. Arb Zool Inst Univ Innsbruck 3:9-16

Sullivan DS, Bisalputra T (1980) The morphology of a harpacticoid gut: a review and synthesis. J Morphol 164:89-105

Tanaka O, Omori M (1992) Additional report on calanoid copepods from the Izu Region, Pt 6. Phaennidae. Publ Seto Mar Biol Lab 35:253-271

Editorial responsibility: Otto Kinne (Editor),

Oldendorf/Luhe, Germany
Terazaki M, Wada M (1988) Occurrence of large numbers of carcasses of the large, grazing copepod Calanus cristatus from the Sea of Japan. Mar Biol 97:177-183

Toda T, Suh HL, Nemoto T (1989) Dry fracturing: a simple technique for scanning electron microscopy of small crustaceans and its application to internal observations of copepods. J Crustac Biol 9:409-413

Wada M, Yamamoto I, Nakagawa M, Kogure K, Ohwada K (1995) Photon emission from dead marine organisms monitored using a video recording system. J Mar Biotechnol 2: 203-209

Weikert H (1977) Copepod carcasses in the upwelling region south of Cap Blanc, NW Africa. Mar Biol 42:351-355

Widder EA, Lats MI, Case JF (1983) Marine bioluminescence spectra measured with an optical multichannel detection system. Biol Bull 165:791-810

Wiebe PH, Copley N, Van Dover C, Tamse A, Manrique F (1988) Deep-water zooplankton of the Guaymas Basin hydrothermal vent field. Deep-Sea Res 35:985-1013

Yoshikoshi K (1980) On the structure and function of the alimentary canal of Tigriopus japonicus (Copepoda; Harpacticoida), II. Cellular renewal in the mid-gut epithelium. Bull Jpn Soc Sci Fish 46:705-710

Young RE (1983) Oceanic bioluminescence: an overview of general functions. Bull Mar Sci 33:829-845

Submitted: April 19, 2001; Accepted: August 7, 2001

Proofs received from author(s): January 25, 2002 